\title{
Teaching Writing to EFL College Students in the Big Data Era
}

\author{
Jianying Yang \\ School of Foreign Languages \\ China West Normal University \\ Nanchong, P. R. China \\ e-mail: yangjianying23423@163.com
}

\begin{abstract}
The wide spreading of the Internet and Web-based appliances help human beings enter into the big data era. The big data era provides teaching writing to EFL college students with abundant resources, technology-based teaching aides and new ideas. In this situation, teaching writing is facing opportunities and challenges in its reform. EFL college teachers and students need to use various online and offline resources based on technology. Therefore, it is necessary for students to grasp enhance their multimodal learning and to cultivate their autonomous learning in studying writing. Fundamental writing skills also need to be improved, and other strategies such as error correction, brainstorming, journal writing and peer review, are equally important in raising EFL college students writing ability.
\end{abstract}

Keywords— the big data era; EFL college students; multimodal learning; autonomous learning

\section{INTRODUCTION}

With the development of new technologies in the $21 \mathrm{st}$ century in recent years, human beings have entered the big data era. The applications of technology also pushes education onto a new stage. The massive open online courses, online universities and the use of hi-tech educational products, all have greatly expanded learners' learning opportunities. The big data era welcomes challenges in enhancing students' English writing abilities, too. People who are good at English writing are needed in most fields, so it is necessary and urgent for Chinese EFL college students to improve writing abilities.

For quite a long period of time it is a very difficult job for EFL college students to write English well. The following are problems for student's writing. Firstly, EFL college students do not read English much and often; the poor input of the English language leads to their poor output in writing well. Secondly, the lack of writing skills prevented them from improving their English writing. Thirdly, they seldom make an overall training plan for English writing and they even seldom practice their English writing, so to get high scores seems rather difficult for them. In addition, they use simple Chinese logical thinking in writing, which does not conform to English way of thinking. On the other hand, EFL writing teachers seldom give the correct guidance to the students and they even pay little attention to English writing themselves, which may make their altitudes affect their students. All these problems confine the writing ability of students.

\section{THE IMPORTANCE OF THE REFORM OF TEACHING WRITING IN THE BIG DATA ERA}

In the big data era, English reading and writing is becoming more and more important. Accordingly, the importance of English writing is becoming increasingly obvious. So English teachers should know that the writing is very important for our students, and at the same time we should realize the teaching of writing is especially significant for us, not only for its practical value in helping our students to get high marks in their exams and have better communication with others, but also in helping our students to express their ideas, thoughts, emotions in English.

\section{A. Writing as a Basic Measurement for Linguistic Abilities}

Writing is considered as the secondary media of communication. Strategies in English writing have been studied in many disciplines and from many perspectives. Generally speaking, the aims of language teaching are usually termed through the four skills: speaking, listening, reading and writing. Strategies in improving English writing are the association between linguistic ability and applicability. Writing is a complex thinking process in which writers explore thoughts and ideas and present them in visible words. Consequently, the importance of writing is easily seen. Writing has something to do with grammar and vocabulary; more importantly, it has something to do with one's thinking and intellectual and emotional exhibition.

Writing serves as a tool in teaching all language skills. It can be integrated with the teaching of listening comprehension, oral presentation, and reading skills. For example, making notes and writing summaries can be used in teaching listening comprehension, writing outlines and scripts can be used for the preparation of oral presentation, and writing can be integrated with the teaching of reading skills by asking the students to write answers to reading comprehension questions. Additionally, writing should be viewed as ways and means to learn a foreign language. Writing, as a teaching means, helps students learn more language knowledge and writing skills that can be used to communicate with others. 


\section{B. Ways of the Reform of Teaching Writing in the Big Data Era}

In the big data era, teaching writing encounters various kinds of opportunities and challenges. Different resources and means of communication exhibit a colorful picture in front of the educators and teachers in view of the reform of teaching writing.

\section{1) Resources and materials for teaching writing}

In traditional teaching writing, teachers usually rely on printed textbooks to explain writing techniques and related knowledge. In the big data era, there are various kinds of resources for teaching writing, including written text, audio materials, audio-visual materials, teaching videos, online live classroom, and so forth. What's more, different types of corpora, search engines and search tools also make it possible for efficient teaching writing. Chinese researchers of English have found it helpful to use corpus search tools such as WordSmith and AntConc, and search engines such as Google, in writing contents, vocabulary and collocation [1] [2].

\section{2) Technology-based teaching aids for teaching writing}

One of the priorities of teaching writing in computer-based internet environment is that the information related to certain topics can be searched online during writing. In the first place, Online search engines provide specialized search tools, which makes it convenient for clients. Online digital resources in digital libraries, too, contain plenty of resources such as magazines, academic periodicals and monographs. In addition, more and more databases can be used in teaching writing. For example, the thesaurus-like database WordNet developed by Princeton University helps English writers in distinguishing word meanings and groupings of words. There is also the online writing system Pigai developed by Beijing Cikuu company, Writing Roadmap by CTB/McGraw-Hill Company, and Noodletools by the American company Noodle Tools Incorporation. These writing systems are based on some big corpora and can give advice on students' vocabulary, grammar, context, content and logic. This function of the writing systems diminishes students' anxiety in their writing process; instead, it arouses students' interest in writing and in revising their writing, enabling the progress of students' writing abilities [3] [4] [5]. At the same time, computer-based internet serves as a bridge for college students to communicate each other more conveniently.

\section{Strategies of TeAching Writing In the Big DatA ERA}

Reading information as background knowledge plays an important role in writing. During the process of learning English, many learners agree that. It is essential for all the English learners. However, it is strange that many students pay more attention to words and sentence structures, ignoring organization and content. They often find themselves having great difficulty in English writing. The infiltration of cultural background knowledge plays a very important role in teaching English writing, which helps English learners to understand the reading materials better as well as improves teaching efficiency.

Teaching writing is of great value in helping our students to compose all types of writing in helping them to have a good command of all language skills in English. At the moment, most of the teachers of English are trying their best to make their students improve their written English. But how to improve students' writing abilities isn't easy. Students had better put all their hearts into it and pay more attention to grammar, spelling, phrases and so on. There are still many problems in our English writing teaching. It is clear that teachers' work is the key to solving the problems, especially in the modern high-tech era when there are various kinds of resources to use. Thus, it is urgent and responsible for teachers to explore some methods of improving students' English writing ability in guiding students making good use of the high technology.

\section{A. Encouraging Students' Multimodal Learning}

Human beings are in a multimodal world with a variety of multimodal texts, written, visual, audio, audio-visual, and so on [6]. College students are readers of these multimodal texts and writers of multimodal texts too. Researches show that the visual modality and the audio modality are the two most important modalities in EFL classroom. The visual modality helps to arrange the classroom and to represent the relationships between the teacher and the students; while the audio modality helps to organize the teaching process of the English language. EFL teaching and learning can be regarded as a semiotic designing activity, with the EFL teacher as a meaning mediator, making meaning with EFL learners in the process of designing and redesigning by using different semiotic resources [7] [8]. Teachers need to encourage students to read different kinds of materials, including written texts, graphs, pictures, audios and audio-visuals, which help to widen students' horizon and help students to think profoundly in the process of writing. At the same time, college students need to use different kinds of modalities to write, such as illustrating ideas by drawing graphs and using videos apart from by producing language.

\section{B. Cultivation of Students' Learning Autonomy in English Writing}

It is pointed out that the useful things in writing are word choice, use of appropriate grammar, syntax, mechanics, and organization of ideas into a coherent and cohesive form, focus on audience and purpose, and the recursive process of discovering meaning [9]. Therefore, it isn't difficult to understand that the quality of a piece of writing is affected by the writer's communicative ability, linguistic ability and writing strategy.

According to the psychology of the students, they will voluntarily do the work which they are interested in and which they have self-confidence to do well. So teachers should try their best to arouse students' interest and help them build up self-confidence. As we all know, all young students are curious about what they will learn and they want to learn well at the beginning. But some students will show no interest and even give up learning after a time. So in English writing teaching, what teachers should do first is how they can make students interested in English writing all the time. Some vivid training methods can be adopted by teachers. In the past several years, many Chinese universities are using the writing system Pigai 
and statistics from its website show that students indeed revise their writings repeatedly and passionately under the suggestions of the system, only with teachers' online monitoring and occasional guidance.

\section{Consolidation of Fundamental Writing Skills}

It is advisable for us to ask our students to do some studying with the set phrases and sentences structures, to keep a list of them and then try to make some sentences with them according to the English grammar knowledge in each class as often as possible. For example, teachers can ask students to make sentences with new words and phrases that they have just learned. If they can write down some correct sentences with the new words by themselves, they are sure to write more sentences that are more complex, and they will gradually write down various long sentences. At the same time, we can still let them translate a few more interesting sentences so that they will be interested in making sentences; and if they keep on making sentences, they will be confident in writing sentences, and they will also be confident in writing compositions, because phrases and sentences are the basic requirements for the students of English and are the base of a good composition.

\section{Brainstorming in Teaching Writing}

Brainstorming is found to be a very good way used in EFL writing class [10]. First of all, we could arrange the class into several discussion groups, each with a secretary to write down all the ideas proposed by the group members. The secretary then reads the draft aloud to the group for them to review and make changes. This process could carry on for some time until all the members are satisfied with the content and structure. Then the group could read the draft one by one to check its spelling, punctuation, and grammar. After this drafts made by different groups could be exchanged to receive comments from each other on restructuring or revision. And then we could also arrange the class into a kind of workshop, where we provide students with rough paper, scissors, paste, erasers, etc. for them to cut and change the structure of their first draft. While the process is going on, we could intervene to provide help for them through questioning and advising. Besides, drafting and redrafting could be carried out in a more interesting way if we have access to computers, since cutting and pasting on computers can be done more easily and provide an enjoyable experience for the students. Another great advantage is that students can see their revised version immediately on the display screen. The massive internet materials and digital materials provide college EFL teachers and students with abundant resources in brainstorming in writing classrooms.

\section{E. Ways of Dealing with Errors}

Most students find it very depressing if they get a piece of written work back and when it is covered in red ink, underlines and crosses. That is terrible for students. But even in these cases, teachers have to achieve a balance between being accurate and truthful on the one hand and treating students sensitively and sympathetically on the other. Some techniques can be used in dealing with the errors in student compositions. We need learn hard work to support the language strengths students already have, proving students with a feeling of success, finding materials, online or digital, and planning classroom experiences will turn students on to writing; students writing progress will develop with much greater ease than it does at the present time. Here are some ideas about how to correct the errors in student compositions.

Rather than engage in intensive error-correction when responding to student writing, teachers are encouraged to adopt a more moderate approach to error. If a teacher over-corrects the students' mistakes, the students would be likely to focus on errors instead of ideas. Students are more likely to grow as writers when the teacher's primary purpose in reading student papers is to respond to content. It is more helpful to select one or two kinds of errors an individual student is making than to point out every error in the paper. Teachers can identify a selected error, show an example or two on the student paper, and either explain the correct form or direct the student to a handbook for further explanation. It is always worth writing a comment at the end of a piece of written work rather than just writing short expressions like "Well done".

Another method for working with student error, one that can be especially fruitful for teachers, is to approach it from an analytic perspective. Teachers, as error-analysts, looking for patterns in the errors of an individual student, try to discover how the mistake arrived at the mistakes by analyzing the errors, especially when students lack knowledge about a certain grammatical point, a careless rule or a misunderstood one.

\section{F. Other Useful Ways in Teaching Writing}

As we say "Practice makes perfect." If we want to improve the students' writing ability, we have to require them to practice writing step by step. In order to achieve the aim, they can take the following steps.

\section{1) Journal Writing}

Journal writing is thought to be a useful way to enhance EFL learner's writing abilities. Findings show that EFL learners' writing fluency, accuracy, and motivation are all enhanced, and that journal writing establishes a close rapport between teachers and learners. Through learners' journal entries, teachers are able to measure learners' language competence and understand learners' needs, though, and feelings [11]. Therefore, keeping English journals is one of the most effective ways to improve students' English writing abilities. It can help teachers to cultivate students' habit of thinking in English. What EFL teachers need to do is to encourage the students to keep journals regularly.

\section{2) Peer Review}

Peer review is a typical process in process writing, whereas it is still an important technique used in designing teaching writing. Students are organized in pairs or groups and review each other's writing, during which process, students ask questions, giving advices and helping correcting mistakes. Successful peer review is a kind of cooperative learning in writing; it reinforces reader awareness [12][13]. In class, teachers should require students to finish writing in 25 minutes. After students finish writing, teachers can show a model article on the screen and explain requirements of correcting articles. First, let each student correct his or her own articles, considering that the sample article is unlikely to show all kinds 
of expressions and that students may make different errors in their articles. Teachers also need to require students to correct articles each other. The best way is to divide students into many mutual help study groups beforehand. Then students correct other articles in groups .On the one hand, students can help each other to improve their writing ability by communicating with others in the activity; on the other, students may avoid making the same mistakes that can be found in other articles.

\section{CONCLUSION}

In the big data era, writing obviously becomes a comprehensive ability based on reading. Strategies of teaching writing are discussed to improve EFL college students' English writing skills. We teachers need to know the importance of high technology to modern English writing. This makes it possible for students to develop the interest of writing in English. Of course, the right guidance of teachers is also important and the strategies of English writing are useful too. Students must comprehensively use the knowledge they have learned. In addition, our society should give some help to schools to build some equipment and establishments which are helpful for students to study writing better, and increase the investments and devotions in English writing, such as buying more English writing books and reading books. As English teachers, we should cultivate the students' habit of writing and train the ability of listening, speaking, reading and writing in all areas and let students keep reading and writing as much as possible. Writing must be processed in an orderly way and must be done step by step. What's more, we teachers should try our best to learn the modern educational technology and make good use of the advanced technology in teaching writing.

\section{REFERENCES}

[1] H. Yue, "Using AntConc to create a small-scale corpus for EFL class," Journal of Henan Institute of Engineering, 2008, 20(4): 44-47.

[2] H. Liu, J. Y. Wang, Y.P. Xia and Y. Yang, "Study on lexical characterist ics of engineering students' English writing", Foreign Language Researc h, 2009, (2): 121-123.

[3] J. L. Tang and Y. A. Wu, "The application of writing automatic evaluation system to college English teaching," Foreign Languages and Their Teaching, 2012, (4): 53-59.

[4] Y. Wang and Z. Y. Li, "A critical review of electronic feedback in second language writing," Computer-Assisted Foreign Language Education, 2012, (7): 11-16

[5] H. X. Wang, "Reform in the teaching of college English writing in the big data era", Modern Distance Education Research, 2014, (3):66-72.

[6] G. Kress, and T. van Leeuwen, Multimodal Discourse: The Modes and Media of Contemporary Communication. New York: Oxford University Press, 2001.

[7] J. Y. Yang, and P. Du, "Meaning making in multimodal EFL learning: a cognitive approach," Journal of the Chinese Society of Education, 2012(S1): 51-52

[8] J. Y. Yang, "The construction of meaning in EFL multimodal classroom with modern educational technology," Journal of Tianjin Foreign Studies University, 2014, 21(4): 59-64.

[9] J. G. Gebhard, Teaching English as a Foreign or Second Language. Mic higan: University of Michigan Press, 2006.

[10] S. S. K. Ibnian, "Brainstorming and essay writing in EFL class," Theory and Practice in Language Studies, 2011, 1(3):263-272.
[11] L. T. Tuan, "Enhancing EFL learners' writing skill via journal writing," English Language Teaching, 2010, 3(3): 81-88.

[12] S. S. Minchew, and V. R. McGrath, "Lasting benefits of cooperative editing for remedial freshman composition students: a follow-up study," Community College Journal of Research \& Practice, 2001, 25(8): 591606.

[13] R. Badger and G. White, "A process-genre approach to teaching writing,” ELT Journal, 2000, 54(2):153-160. 